\title{
Survey Report: Natural Resource Use, Environmental Management and the Minorities in Indonesian Islands
}

\author{
HONG, Sun-Kee (corresponding author) \\ Institution for Marine \& Island Cultures, Mokpo National \\ University, Republic of Korea \\ landskhong@gmail.com
}

\author{
Luchman Hakim \\ Brawijaya University, Indonesia
}

Publication Information:

Received 4 November 2018, Accepted 21 November 2018, Available online 31 December 2018 doi: 10.21463/jmic.2018.07.2.07

\begin{abstract}
Since 2010, we are conducting a survey on the living resources and the living culture of the inhabitants of Lesser Sunda Islands, Indonesia. Indonesia is an island nation rich in natural resources and culture. Because Indonesia is a multicultural country with many languages, tribes and ethnic groups, understanding of Indonesia is essential for understanding the minority languages of each region. There are abundant resources such as timber and oil in the Kalimantan region of Indonesia. It has long been used as a colony of western countries, and resource plunder has occurred. In recent years, KORINDO (Korea-Indonesia Joint companies) have been involved in the illegal logging of wood in East Kalimantan, causing social problems. Indonesia is made up of more than 13,000 islands, and Bali and Lombok have a unique ecosystem and culture for each island, and many tourists are looking for it. Especially the Bali, which is a Hindu, is a very important tourist destination to be visited by tourists from all over Asia including Australia and Germany. Recently, however, environmental problems including marine litter have been raised, showing the limit of environmental capacity of Bali. The Indonesian government is, therefore, developing Islamic Lombok Island, as a tourist destination that is a substitute for Bali. Since most Indonesian islanders are engaged in fishing, they have been able to travel between islands and islands for a long time using vessels. To understand marine culture, life history and eco-cultural studies on the major minority tribes of each island are essential. In particular, it is necessary to understand traditional knowledge about how natural resources are used.
\end{abstract}

\section{Keywords}

Bajo tribe, Bali, East Kalimantan, Gili, Lombok, Lesser Sunda Islands, Pulan Bungin, Sumbawa 


\section{Desolation of East Kalimantan and Pulau Derawan Island}

In order to get to Pulau Derawan Island which is located in the northern part of East Kalimantan, Pulau Borneo, after a flight to Balikpapan, another domestic flight to North Samarinda is needed. And from Samarinda, another travel by a car is left to the port of Pelabuhan Tanjung Batu. The view from Samarinda to Pelabuhan Tanjung Batu is truly a surprise. Most of the tropical forest vegetation that are seen on the road were cut down and the devastated soils were all exposed and heated up from the blazing sun. And from time to time, peoples who were secretly setting up the forest fire were seen. Borneo Island is a globally recognized jungle, and is known for a home to many different living things, however its eastern coast of East Kalimantan was almost a devastated land itself. All the rivers across Samarinda were all polluted with murky stream and were busy with cargo ships carrying logs and coals. It was known that Indonesia is a country where $73 \%$ of its territory is forests, and possess a global tropical forest resources. In particular, the Borneo Island has a large amount of logs, oil and coal, which had been an arena for competitions for European powers in the age of imperialism.

Unlike other regions, East Kalimantan on Borneo Island is Indonesia's richest region, with per capita GDP of more than $\$$ 10,000 (as of 2008). It is because centering Balikpapan, this area produces large amount of oils and coals. And the problem is that the local authorities in Indonesia is out of controlling the illegal logging in order to cut down the natural forests. Because a normal forest is not allowed to be used as a lumber site, they set up the forest fire on purpose and cut down the main trees. The local government officials are conniving it even though they are aware of this situation. Once the forest fire breaks out, the logging is started on the extinguishing process (Figure 1). On the logged parts, large amounts of palm trees are planted for the production of the palm oil (Figure 2). Korea has long been involved in the logging industry in Indonesia, and the KORINDO group is the representative Korean-Indonesian company. this company has invested in logging, reforestation, plywood and palm oil production of Indonesia, and more Korean companies are said to invest in these areas to log and plant trees. Recently, Samsung SDS, in cooperation with this company, tried to enter in the mentioned industries of Indonesia but call off the cooperation upon hearing the infamous rainforest destruction news about KORINDO.

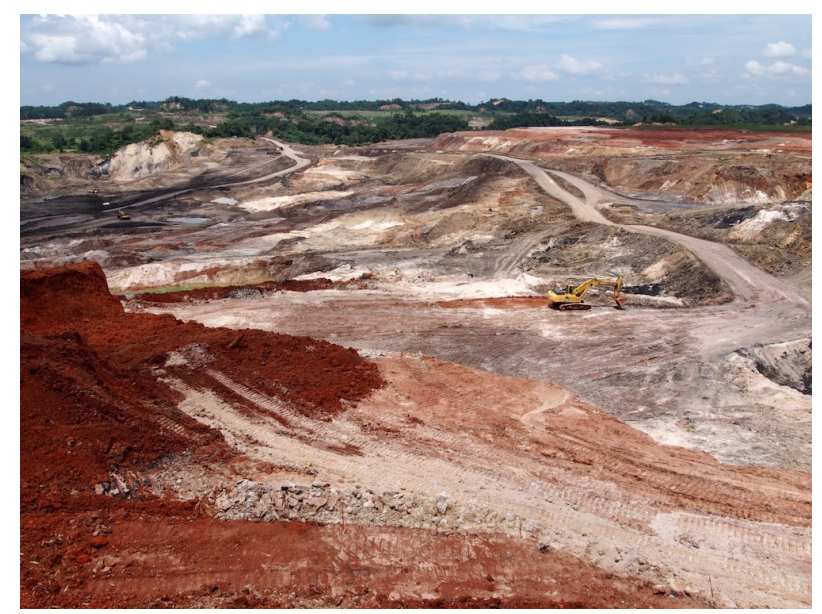

Fig 1. Coal mining near Samarinda in East Kalimantan. (Photo by Hong, S.K.) 
Samarinda is in the delta surrounded by Mahakam River tributary that logs and coals are carried through. When Samarinda is reached, in the nearby port, it is loaded again and move to Java Island. In fact, the cities in East Kalimantan including Samarinda almost never have logs or coals processing factories. Mostly it is only about producing and distributing the raw materials. Looking at the colors of the rivers across Samarinda, the health of the residents in this area is worried. The writer of this research has met the local environmental officials to inquire and discuss on this issue, but their answers are consistent; the residents are safe. Rather, they were more concerned on the over-introduction of foreign capital into the region. There are invisible complaints in the provinces since the projects are being developed or determined in a top-down manner by central government that it is not progressed democratically nor undergoes the environmental impact assessments.

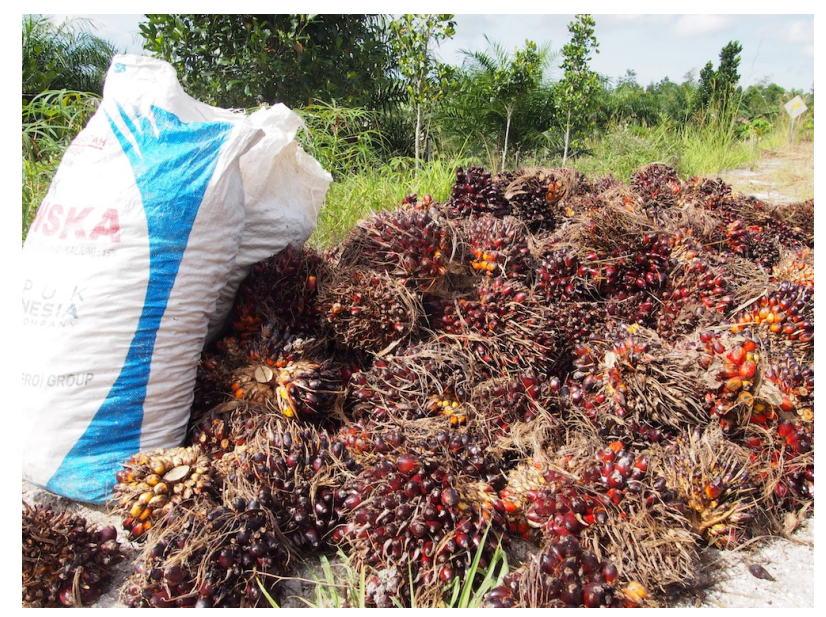

Fig 2. Oil palm seed in the street in East Kalimantan. After the lumbering the tropical forest, oil palm plantation is major business in this area. (Photo by Hong, S.K.)

East Kalimantan is rapidly undergoing not only logging development but also mining development. Some residents claim that logging is not a practical goal but only a first step for the mine development. As mine development is progressing, so is oil development. For developers' standpoint, it is like catching the three birds with one stone. The logs are collected through cutting down process, then the coals are collected through mine development and the last process is the oil development. In recent years, East Kalimantan has been attempting to identify and adjust the problems of such a vicious land development. They try to make efforts like planting the alternative crops, processing the restoration works and reorganizing of industrial structure. However, the central government does not have an alternative policy for restoration of mining areas. In response to the power of the central government, local governments are trying to solve the environmental problems on their own, but they cannot solve the complex environmental problems such as logging, mining, and soil leaking on a large scale without central government cooperation. Resources were exploited by imperialistic world powers and it was also suffered from Japanese militarism during World War II, and now by multinational corporations, including Korindo of Indonesia, Borneo Island of Indonesia is thoroughly tanked. The East Kalimantan government is considering tourism as a new industry, and its goal will be the Kepulauan Derawan Derawan. The Derawan islands is the largest coral reef island in the East Kalimantan region and a diver's paradise (Figure 3). In order to avoid the thoughtless development and to maintain the natural beauty of the islands, it is desirable to refuse the large-scale business investment which throws the residents out. It is truly wished that the East Kalimantan government, 
which has watched the thoughtless development of companies such as Korindo, makes a wise decision in the island development.

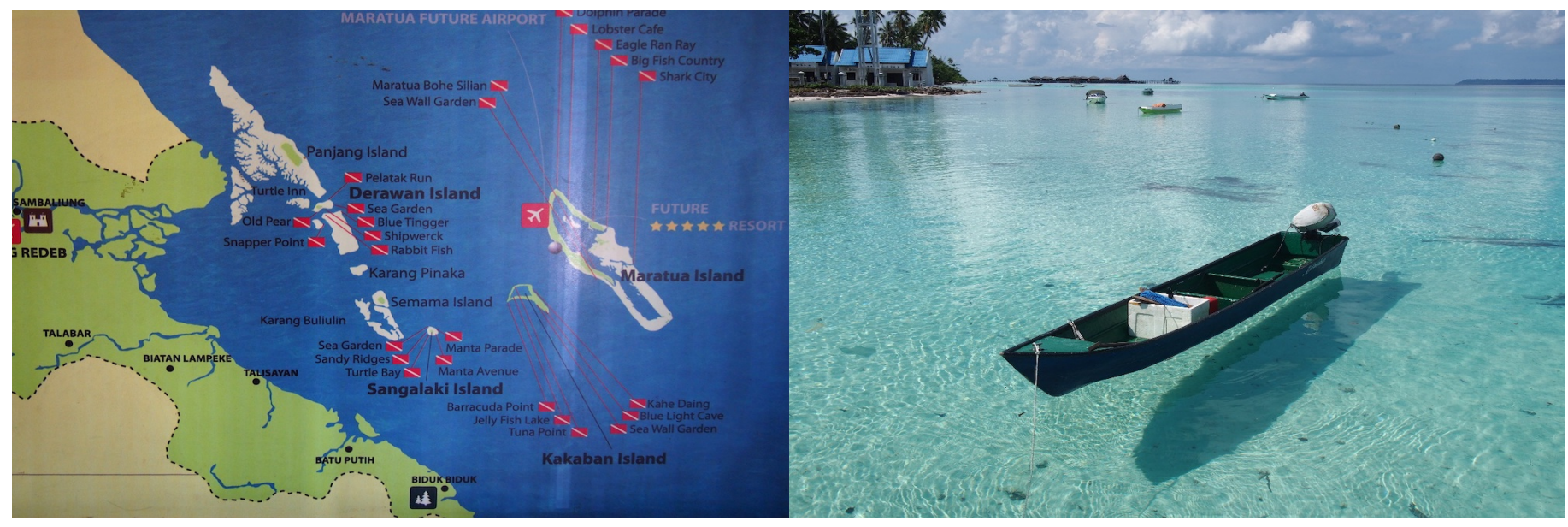

Fig 3. The East Kalimantan government is considering tourism as a new industry, and its goal will be the Pulau Derawan. The Derawan islands is the largest coral reef island in the East Kalimantan region and a divers' paradise. (Photos by Hong, S.K.)

\section{Is it Sustainable Tourism?: The Case of Bali and Lombok}

There is a word 'Cultural imperialism'. It refers to not only about looking up to its own culture; it is also about applying it to other countries (Gaunette and Dogan, 2015). In the course of World War II, many colonies became independent in Asia, and the powerful powers who lost their colonies found new governance systems in various ways because they could not control the independent countries. The characteristic of culture imperialism is that before the independent countries become self-supporting, the powerful countries set the cultural subordination to them so that they have to depend on the powerful countries especially their multinational corporations, tourism industries, and the media (movies). Surely, some people may be positive on this in terms of expanding the universal human culture, but in the end, most of them have negative effects such as loss of cultural identity, destruction of traditional culture, disappearance of indigenous language, and destruction of unique ecosystem. Southeast Asian countries, such as the Pacific Islands like Indonesia and the Philippines, which once were colonies of the European tropical powers, became independent countries after World War II, but it is reality that they still have economic, political and cultural influences from their original empires and is also applied to the preference on the tourism development areas (Hong et al., 2014). 


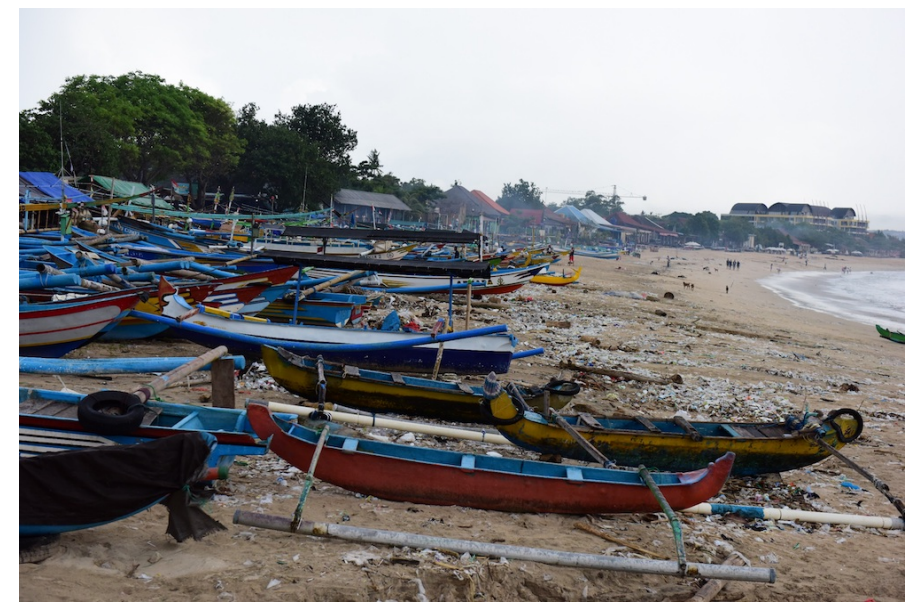

Fig 4. Environmental problem of marine litter and debris on the Bali's coast is a major obstacle to tourism. (Photo by Hong, S.K.)

Lombok (Pulau Lombok) is a new favorite tourist destination located on the east side of Bali island of Indonesia. Compared to Bali, it has not yet been developed that not many people visit, but is newly famous for a honeymoon destination for Koreans. Lombok is famous for a spot for Wallace Line, the biological and geographical boundaries that British naturalist Alfred Russell Wallace left while investigating the Malays Islands. The Wallace Line is a well-known theory for biogeographers (Michael, 2002), which divides through the Lombok Straits between Bali and Lombok along the Makassar Straits between Borneo and Sulawesi. In Lombok, there is an active volcano Mount Gunung Rinjani at an altitude of $3,726 \mathrm{~m}$, and there are many beautiful beaches that attract many visitors around Senggigi, the downtown area.

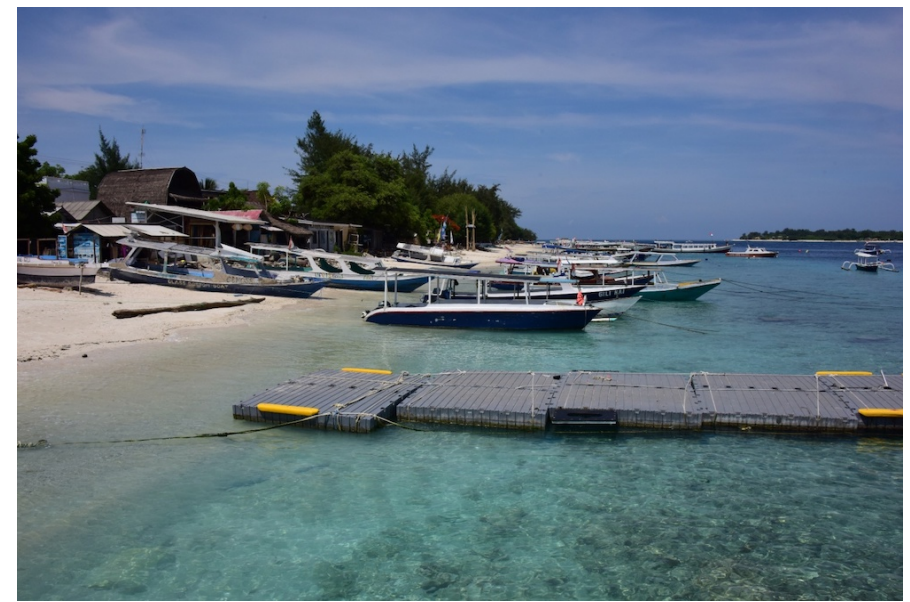

Fig 5. Coral beach in Gili, Lombok. (Photo by Hong, S.K.)

Bali in the west of Lombok has been developed as a foreign resort since Indonesia was a Dutch colony (Khamdevi and Bott, 2018). With its Bali Hindu temples and costumes that are decorated with distinctive patterns and the impressive maritime and rural landscapes have combined to create a global tourism destination in the 20th century (Hakim et al., 
2009). The quiet Bali has been changed a lot as tourists from Chinese group have been gathering since 10 years ago. In the past, the tourism industry has developed only in the traditional villages such as Denpasar and Kuta, but with the mass Chinese tourists recently, large-scale shopping centers and duty-free shops are emerging. Bali has suddenly become a very unfamiliar place for Westerners. The Indonesian government is preparing to develop Lombok as an alternative to Bali. The writer of this research has visited various beaches and rural areas of Lombok islands and identified various tourism resources. The sands in the northern coast is relatively black and the southern part sand was white. Probably the color of the sands in northern coast is due to the geologic characteristics associated with the active volcano mountain Gunung Rinjani, but both of them was beautiful and great natural beaches. After hearing from the local residents about the tourist attractions development, it was surprising to know that the Indonesian government is exclusively investing on the white sand beaches. And the answer on why they do not invest on black sand beaches was very simple; the Westerners definitely prefer white sand beaches. Thus, the tourism development that took place in the beaches from Lombok Island and small island (Gili, Figure 5) were all white sand beaches (Hakim et al., 2012; Hakim et al., 2018).

It may sound too excessive but perhaps Indonesian is still following the Westerners' preference on the tourist spots that were acquired from Dutch. And the question on whether the white sand beach should be recognized as a more valuable tourism resource than black sand beaches was raised. At the same time, the write thinks that that there seems to be a similar tendency for the tourist attractions in Korea; an environment awareness that is bound to like transparent East Sea more rather than gray light tidal sea. From where do these perceptions begin? In recent days, groups of Chinese tourists have been flooding in Jeju Island and have again gone like a tide. In this situation of Jeju, it is time to think what and who the Jeju island tourism was for. Through the case of Bali and Lombok, it is necessary to introduce tourism industry infrastructure development and tourist diversification policy in Korea after in-depth examination on the fact that the tourism type centered on the Western people and the tourism type centered on the Asian people are different (Hong and Nakagoshi, 2018), and the resources required by the tourists are indeed different.

\section{Sumbawa and the Bajo tribe of Pulan Bungin}

The most basic things to consider when investigating islands in East Java region of Indonesia are the language and the tribe (Hakim et al. 2007; Stephen, 2014). Obviously, they use Indonesian language but as there are their own unique dialects and the characteristics in each island, it is necessary to have an interpreter in order to work in the island for even someone who was born in Jakarta. Next, to talk about the tribes, there are numerous tribes including Bugis, Madura, Bajo and more. And the characteristics of the island's landscape, economy, and society vary depending on where they have flowed and settled. Sumbawa, which was visited from January 7 to 11,2018 , is located in the central part of the Lesser Sunda Islands where Sumba is located in Lombok on the west, Flores on the east, and Sumba on the southeast. The main tribes of Sumbawa is Sumbawa tribe that occupies the west part of the island, the Sumbawa Besar region and Bima tribe that occupies the east part, Bima region. Language is also slightly different. 


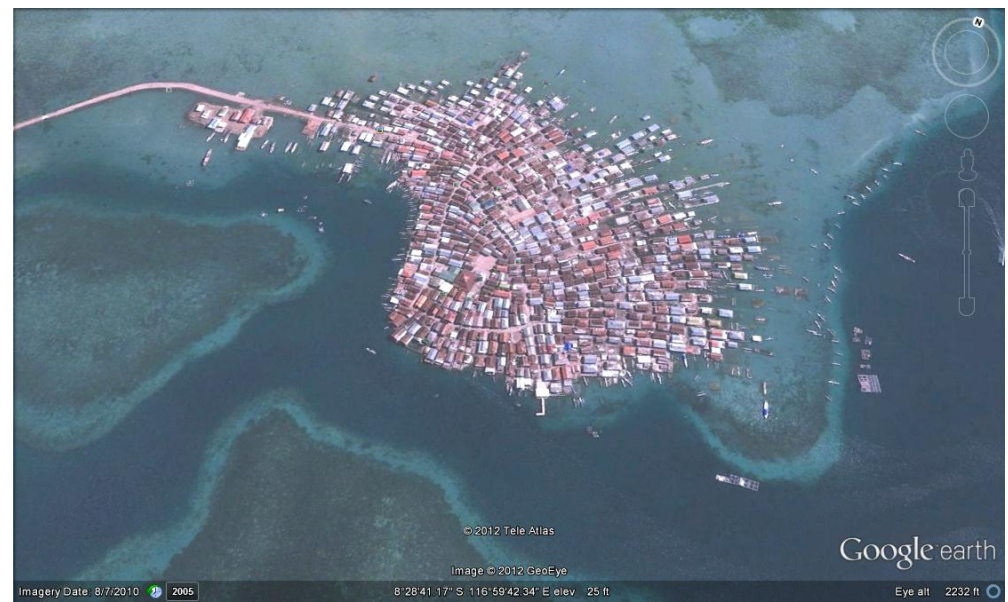

Fig 6. Seascape in Pulan Bungin, Sumbawa Island, Indonesia (photo from Google Earth, sourced from http://ebynhadinata.blogspot.com/2012/09/add-caption-bungin-island-is-floating.html)

Pulan Bungin is a small island located on the coast of Sumbawa Besar. On a Google map, it is very surprising to see numerous houses in just one island (Figure 6). The density of housing and population is known to be the highest in the world knowing this is a single island (Figure 7). It is increasing to 1,700 in 1965 and 3,800 in 2017. The original area was 9 ha, but as the population of the island has increased recently, the surrounding area has been filled as residential areas and is now $12 \mathrm{ha}$. It has been isolated island for a long time but since 2002, as the island got connected to the land, society, environment and culture are changing.

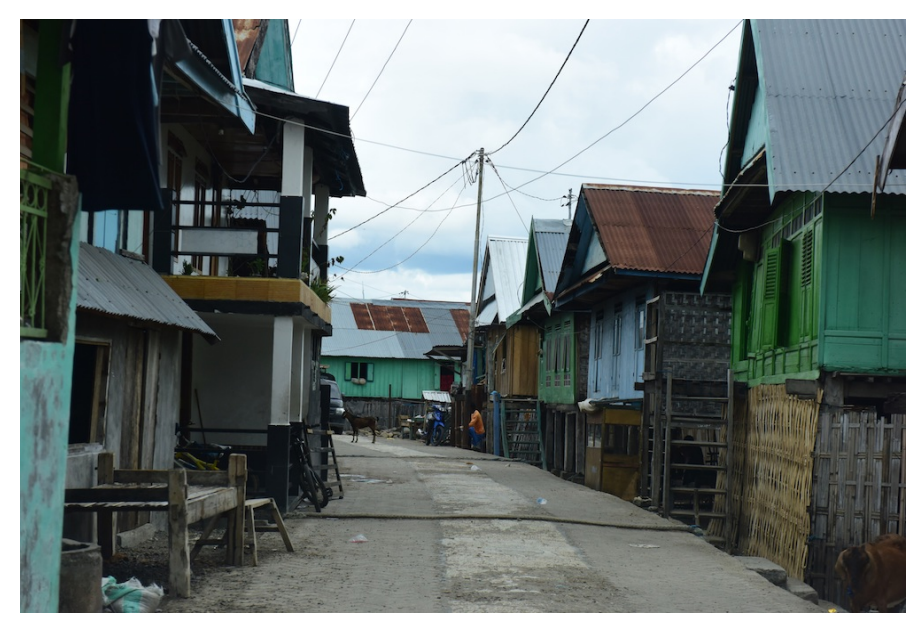

Fig 7. Residence at Pulan Bungin. (Photo by Hong, S.K.)

Generally, the fishing villages in Indonesia are formed mostly by Bugis tribes, and even though the type of housing is completely characteristic of Bugis, surprisingly, here is composed only with Bajo tribe. Most tribes want to stay independent and self-govern while maintaining their own identities and avoid mixing with other tribes. In order to do that, they have to have conditions that allow them to stay independent. Despite the poor environment such as limited area and 
water resources, the facts that the Bajo tribe has not changed their identity and keep it by not marrying with other tribes throughout generations are very interesting. It was very kind and nice of them that it was not uncomfortable at all to be mixed with them in their village. Perhaps it is because their generous minds that they have lived through the sea.

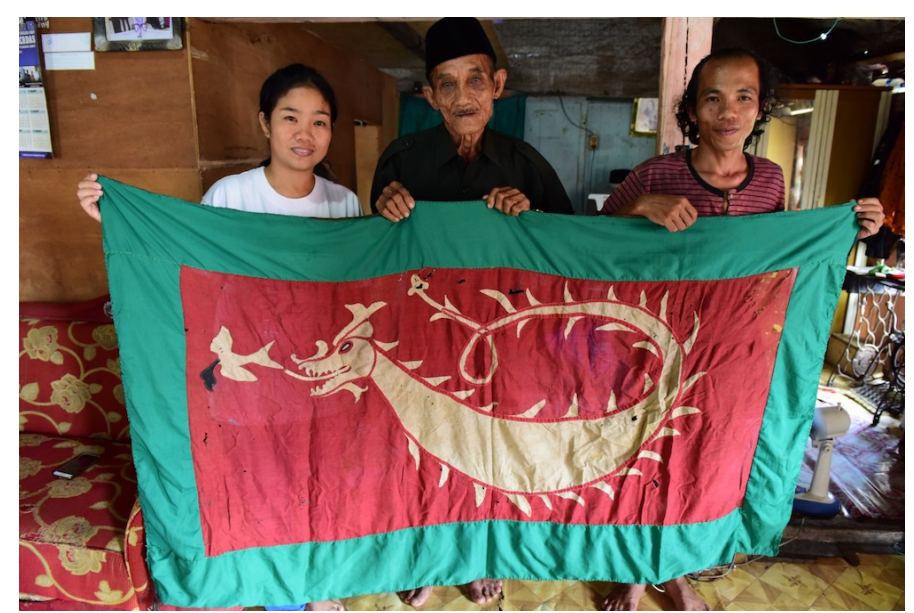

Fig 8. Family flag of Mr. Arif Rahman Makkadia (center). His son, Mr. Hakim (right) and daughter (left). (Photo by Hong, S.K.)

The writer entered to the island village and asked for an interview with the elderly representative, and luckily, was able to meet the oldest man in the village, Mr. Arif Rahman Makkadia who is 83 years old (Figure 8). In fact, the writer was able to meet his son, Mr. Hakim, first and then he introduced his father and then met the daughter and had a few conversations together. The old man is the fifth generation who settled down on the island from the southern Sulawesi, and the son is the sixth generation. In other words, they live on an island for hundreds of years. According to the old man, the ancestors of Bajo tribe entered to this island from Sulawesi around 1800 years ago. At that time, the most economic means was fishing. And still now, they specialize in fishing tuna and sardine. The old man was born in 1937 and worked as a fisherman who dives and catches fishes and pearls with bare-hands in his early days, and now he is retired and is enjoying himself as a senior in the neighborhood. He used to have four wives (Muslims allow polygamy), and from first to third wife he had no children, but with fourth wife, he had nine children. When the writer asked him about the connection of the island with the land, he said it now became very convenient for him to go to hospital whenever he is sick but on the other hand, he said it is very noisy since the foreign tourists are "rudely" (word expressed by him) riding motorcycles or cars all over the town. When asked why he is living on this small island not on big islands like other tribes, he answered "That's Bajo".

\section{Acknowledgements}

This manuscript is research conducted with the support of National Research Foundation of Korea (NRF-2009-361A00007) funded by Korean government (Ministry of Education, Science and Technology) in 2009. Our thanks are due to 
Mr. Arif Rahman Hakim at Pulan Bungin, Mr. Ijen Vulano Yacob at Banyuwangi, and Ms. Mardiany at East Kalimantan for their kind cooperation during the survey.

\section{References}

Gaunette S.-M., Dogan, G. 2015. Imperialism and tourism: The case of developing island countries. Annals of Tourism Research 50, $143-158$.

Hakim, L., Mardiany, Hong, S.K. 2018. Enhancing environmental management of small islands for sustainable tourism: case study of Derawan Island, East Kalimantan, Indonesia. Eco. Env. \& Cons. 24 (3), 1422-1429.

Hakim, L., Kim, J.E., Hong, S.K. 2009. Cultural Landscape and Ecotourism in Bali Island, Indonesia. Journal of Ecology and Field Biology 32 (1), $1-8$.

Hakim, L., Soemarno, Hong, S.K. 2012. Challenges for conserving biodiversity and developing sustainable island tourism in North Sulawesi Province, Indonesia. Journal of Ecology and Field Biology 35 (2), 61-71.

Hong, S.K., N. Nakagoshi (Eds.), 2018. Landscape Ecology for Sustainable Society. Springer-Verlag.

Hong, S.K., J. Bogaert, Q.W. Min (Eds.), 2014. Biocultural landscapes - Diversity, Functions and Values. Springer-Verlag.

Khamdevi, M., H. Bott, 2018. Rethinking tourism: Bali's failure. IOP Conference Series Earth and Environmental Science 126(1), 012171. (DOI: 10.1088/1755-1315/126/1/012171)

Royle, S. 2014. Islands: Nature and Culture, first ed. Reaktion Books, UK

Shermer, M. 2002. In Darwin's Shadow - The life and science of Alfred Russel Wallace. Oxford University Press, USA 